Gut, 1960, 1, 345.

\title{
THE EFFECT OF AN ADRENAL INHIBITOR (SU 4885) ON GASTRIC SECRETION IN DOGS
}

\author{
BY \\ J. W. Mcintosh, N. ANDERSON, H. L. DUTHIE, and A. P. M. FORREST \\ From the University Department of Surgery, Western Infirmary, Glasgow
}

There is considerable evidence that the adrenocortical steroids potentiate both human and canine gastric secretion. In this study, the action of the adrenocortical inhibitor, SU 4885, has been observed in dogs having separated pouches of the stomach. No effect was noted on the secretory responses to meat, histamine, or mecothane when the drug was given by single intravenous injection. However, the 24-hour output of acid was inhibited when the drug was given orally for a period of 10 to 14 days. While this effect may be due to the ability of the drug to inhibit adrenocortical function, there is no positive supporting evidence.

The recently synthesized compound 2-methyl-12-bis- (3-pyridyl)-l-propanone (SU 4885, Ciba) has been found to inhibit strongly adrenocortical function in the dog and in man (Chart, Sheppard, Allen, Bencze, and Gaunt, 1958; Jenkins, Meakin, Nelson, and Thorn, 1958; Coppage, Island, Smith, and Liddle, 1959; Jenkins, 1959). Studies in vitro have confirmed that it acts specifically on 11- $\beta$ hydroxylation (Liddle, Island, Lance, and Harris, 1958), inhibition of which depresses the secretion of cortisol, corticosterone, and aldosterone by the cells of the adrenal cortex. The minimum effective dose of SU 4885 bitartrate is $5 \mathrm{mg}$. per $\mathrm{kg}$. body weight and it has been shown that $15 \mathrm{mg}$. per $\mathrm{kg}$. body weight administered intravenously promptly reduces the output of cortisol in the adrenal vein blood (Liddle et al., 1958).

There is considerable evidence that the adrenocortical steroids potentiate gastric secretion in dogs and man and the following studies were undertaken to determine if the administration of SU 4885 had an effect on the secretion of acid and pepsin by the stomach.

\section{METHODS}

Tests of the effect of SU 4885 on gastric secretion were carried out in seven dogs with separated pouches of the stomach of Heidenhain type. In three dogs the effect of a single injection of SU $\mathbf{4 8 8 5}$ on three types of secretory response was studied, and in the remaining four dogs the drug was administered daily for a period of 10 days while the 24-hour secretions from the pouches were being collected serially.

Single InJection of SU 4885.-In three dogs the effect of an intravenous injection of SU 4885 bitartrate
(15 mg. per $\mathrm{kg}$. body weight) on the secretory response from separated pouches to meat, to a parasympathomimetic drug, and to histamine was determined. The dogs were kept under identical living conditions and fed on standard kennel rations; tests were carried out after a 16-hour fast and only when there was no free acid in the basal juice.

Meal of Meat.-After the ingestion of $\frac{1}{2} \mathrm{lb}$. of proprietary tinned meat, juice was collected at 15-minute intervals for four hours. In three tests on each dog an intravenous injection of SU 4885 bitartrate in $0.9 \%$ saline (15 mg. per kg. body weight) was given 15 minutes after the meat had been eaten while in three further control tests a similar volume of $0.9 \%$ saline alone was given.

Mecothane.-In these tests pouch secretion was stimulated by the continuous subcutaneous infusion of 5 mg. "mecothane" (carbaminoyl- $\beta$-methyl choline chloride) per hour at a constant rate using a Palmer injection apparatus. The injection was continued for four hours during which juice was collected from the pouch at 15-minute intervals. In three tests on each dog SU 4885 bitartrate in saline $(15 \mathrm{mg}$. per $\mathrm{kg}$. body weight) was injected intravenously immediately the infusion was started and in three control tests saline alone was injected.

Histamine.-The secretion of juice from the pouch was stimulated by a continuous subcutaneous infusion of histamine acid phosphate, $25 \mu \mathrm{g}$. base per $\mathrm{kg}$. body weight per hour, delivered by a Palmer injection apparatus. When a steady rate of acid secretion had been reached, usually after one and a half to two hours, the juice from the pouch was collected for six 15-minute periods. An intravenous injection of SU 4885 bitartrate, $15 \mathrm{mg}$. per $\mathrm{kg}$. body weight, was then given and collections continued for nine 15 -minute periods. Cortisol hemisuccinate, $100 \mathrm{mg}$., was then injected intravenously and final six 15-minute collections made. Tests were 
carried out on three occasions in each dog while in three further control experiments $0.9 \%$ saline was injected in place of the SU 4885 and cortisol was omitted.

In all the tests juice was collected at 15-minute intervals, the volume measured in millilitres and the concentration of free acid determined by titration with $N / 10$ sodium hydroxide using Topfer's solution ( $p$ dimethyl amino-azo benzene) as indicator. The concentration of pepsin in a 1 in 20 dilution of juice in distilled water was estimated by Hunt's method (1948) using dried human plasma as substrate and determining the amino-acid products of digestion by the FolinCiolteau reaction. The results were calibrated in milligrams tyrosine equivalents per millilitre juice. From these estimations the outputs of acid in milliequivalents and of pepsin in milligrams tyrosine equivalents per 15-minute periods were calculated.

In the responses to meat and "mecothane", statistical comparisons of the total outputs of juice, acid, and pepsin for the four hours of the test were made by an analysis of variance of the logarithms of the outputs.

Continuous Oral Administration of SU 4885.-In three dogs with separated gastric pouches of Heidenhain type, 24-hour collections of gastric juice were made by attaching a polythene bottle to the cannula draining the pouch. The dogs were fed a standard weighed diet of meat and cereal of equal amount each day. After a control period of two to three weeks, crushed tablets of SU 4885 were given each morning in milk for 10 to 14 days. The dose of SU 4885 was $100 \mathrm{mg}$. per $\mathrm{kg}$. body weight per day. Daily collections of juice were made for a further 10 to 14 days after discontinuing the drug.

The volume of each 24-hour collection of juice was measured in millilitres and the concentrations and outputs of acid and pepsin were estimated as above. From these volumes the daily outputs of acid and pepsin were calculated.

The means of the logarithms of the outputs of juice and pepsin in each phase of the experiment for each dog were analysed statistically by Student's $t$ test.

\section{RESULTS}

Single Intravenous InJection SU 4885.-The results are for three dogs.

Response to Meat.-The intravenous injection of $15 \mathrm{mg}$. SU 4885 per $\mathrm{kg}$. body weight was without significant effect on the volume of juice or the outputs of acid or pepsin from the separated pouches in response to ingestion of a meal of meat. The mean outputs of acid and pepsin for each dog are shown in Fig. 1 and the mean total outputs during the four hours of the tests in Table $I$.
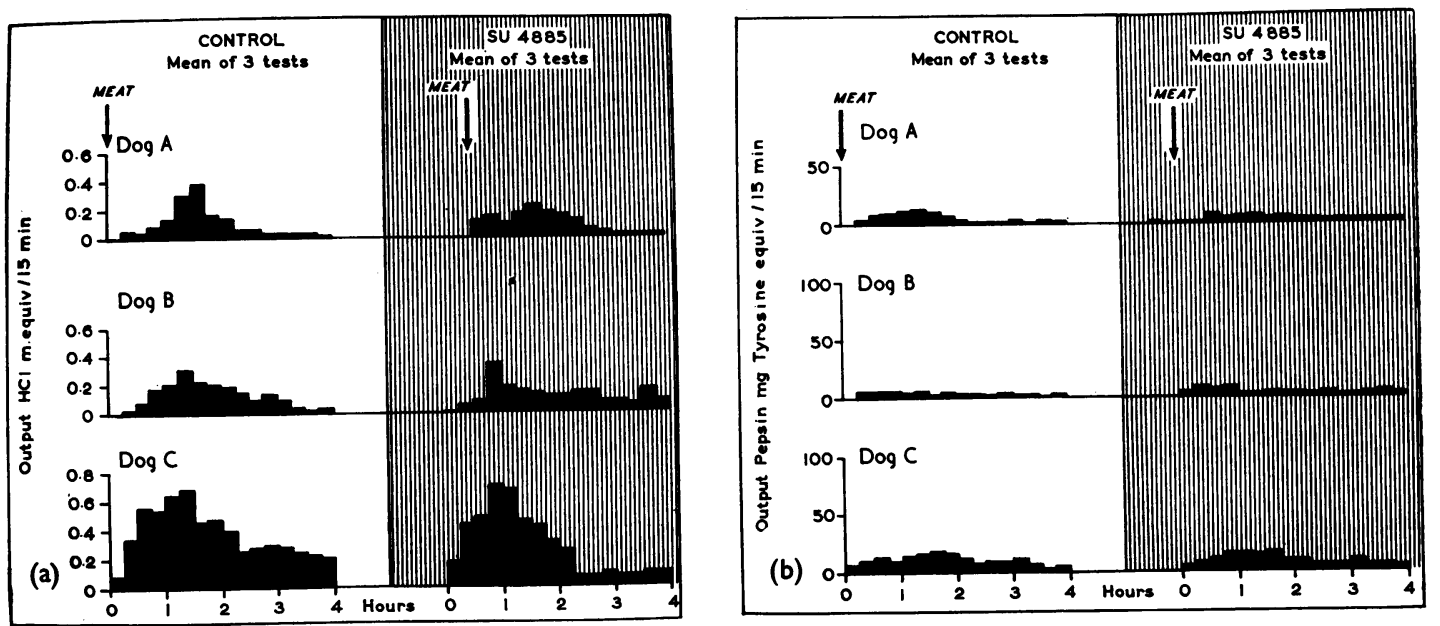

FIG. 1.-The effect of SU 4885 (15 mg./kg. intravenously) on the outputs of (a) acid and (b) pepsin from Heidenhain pouches of the stomach stimulated by a meal of meat in three dogs.

TABLE I

EFFECT OF SU 4885 ON OUTPUTS OF JUICE, ACID, AND PEPSIN FROM SEPARATED POUCHES IN THREE DOGS AFTER STANDARD MEAL

\begin{tabular}{|c|c|c|c|c|c|c|}
\hline \multirow[t]{2}{*}{ Dog } & \multicolumn{2}{|c|}{$\begin{array}{l}\text { Volume Juice } \\
\text { (ml./4 hr.) }\end{array}$} & \multicolumn{2}{|c|}{$\begin{array}{l}\text { Output Acid } \\
\text { (mEq./4 hr.) }\end{array}$} & \multicolumn{2}{|c|}{$\begin{array}{l}\text { Output Pepsin } \\
\text { (mg. tyrosine/4 hr.) }\end{array}$} \\
\hline & Control & SU 4885 & Control & SU 4885 & Control & SU 4885 \\
\hline $\begin{array}{l}\mathbf{A} \\
\mathbf{B} \\
\mathbf{C}\end{array}$ & $\begin{array}{l}15 \cdot 0 \\
22 \cdot 7 \\
42 \cdot 2\end{array}$ & $\begin{array}{l}13 \cdot 4 \\
28 \cdot 9 \\
34 \cdot 5\end{array}$ & $\begin{array}{l}1.499 \\
1.993 \\
5.472\end{array}$ & $\begin{array}{l}1.392 \\
1.983 \\
4.497\end{array}$ & $\begin{array}{r}66 \cdot 7 \\
44 \cdot 1 \\
168.6\end{array}$ & $\begin{array}{r}39 \cdot 5 \\
66 \cdot 7 \\
132 \cdot 8\end{array}$ \\
\hline
\end{tabular}



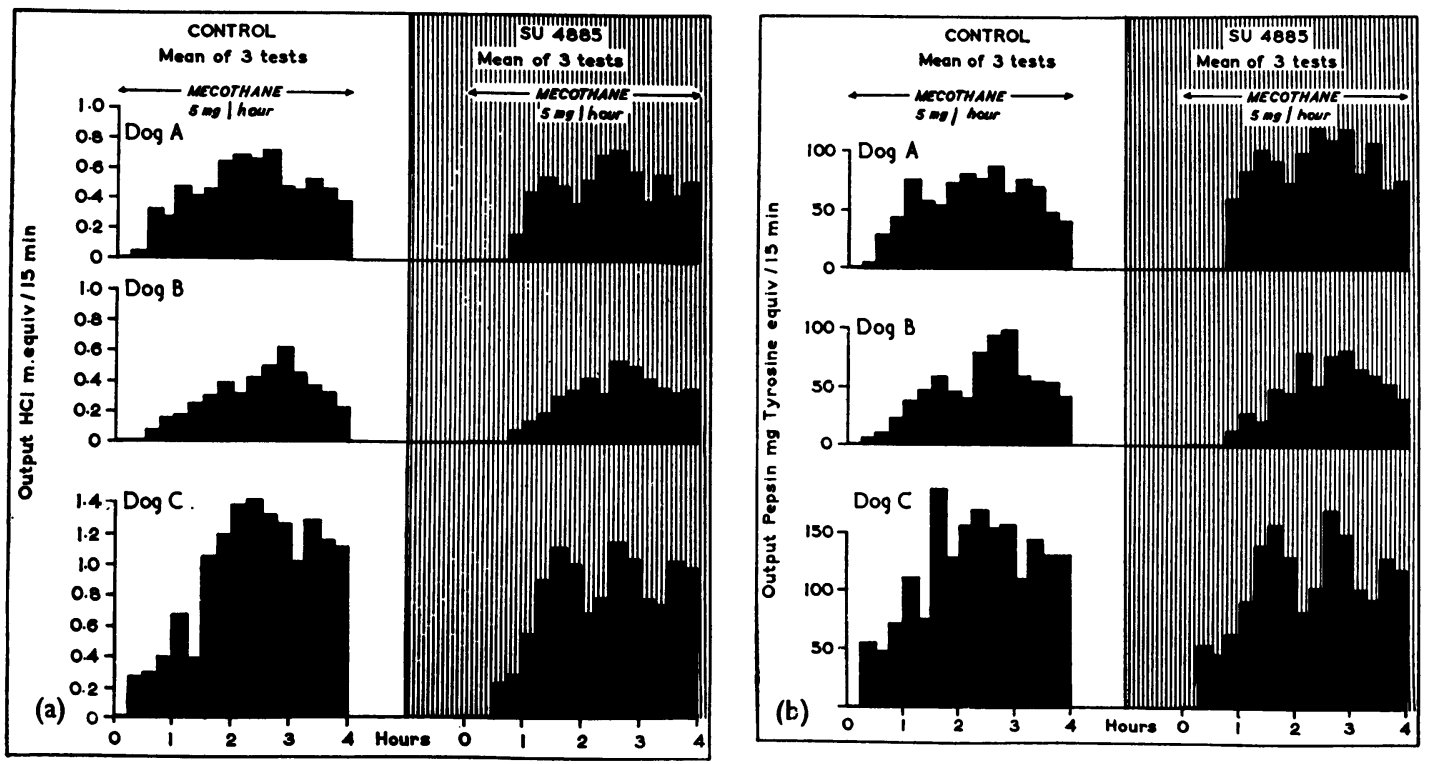

FIG. 2.-The effect of SU 4885 (15 mg./kg. intravenously) on the outputs of (a) acid and (b) popsin from Heidenhain pouches of the stomach stimulated by a continuous subcutaneous injection of "mecothane" ( $5 \mathrm{mg}$./hr.) in three dogs.

TABLE II

EFFECT OF SU 4885 ON OUTPUTS OF JUICE ACID, AND PEPSIN FROM SEPARATED POUCHES IN THREE DOGS STIMULATED BY CONTINUOUS SUBCUTANEOUS INFUSION OF MECOTHANE

\begin{tabular}{|c|c|c|c|c|c|c|}
\hline \multirow[t]{2}{*}{ Dog } & \multicolumn{2}{|c|}{$\begin{array}{l}\text { Volume Juice } \\
\text { (ml./4 hr.) }\end{array}$} & \multicolumn{2}{|c|}{$\begin{array}{l}\text { Output Acid } \\
\text { (mEq./4 hr.) }\end{array}$} & \multicolumn{2}{|c|}{$\begin{array}{l}\text { Output Pepsin } \\
\text { (mg. tyrosine/4 hr.) }\end{array}$} \\
\hline & Control & SU 4885 & Control & SU 4885 & Control & SU 4885 \\
\hline $\begin{array}{l}\mathbf{A} \\
\mathbf{B} \\
\mathbf{C}\end{array}$ & $\begin{array}{r}57.5 \\
49.8 \\
103.8\end{array}$ & $\begin{array}{l}54 \cdot 5 \\
46 \cdot 6 \\
88 \cdot 1\end{array}$ & $\begin{array}{r}6 \cdot 708 \\
4.468 \\
14.493\end{array}$ & $\begin{array}{r}6 \cdot 286 \\
4 \cdot 212 \\
11 \cdot 285\end{array}$ & $\begin{array}{r}869.8 \\
767.2 \\
1859.6\end{array}$ & $\begin{array}{r}1194.2 \\
639.9 \\
1585.5\end{array}$ \\
\hline
\end{tabular}

TABLE III

EFFECT OF SU 4885 AND CORTISOL ON SECRETION OF JUICE, ACID, AND PEPSIN FROM SEPARATED POUCHES IN THREE DOGS STIMULATED BY CONTINUOUS SUBCUTANEOUS INJECTION OF HISTAMINE ACID PHOSPHATE

\begin{tabular}{|c|c|c|c|c|c|c|c|c|c|c|c|c|c|c|c|c|c|c|c|}
\hline \multirow{3}{*}{\multicolumn{2}{|c|}{ Dog }} & \multicolumn{6}{|c|}{ Volume Juice (ml./15 min.) } & \multicolumn{6}{|c|}{ Output Acid (mEq./15 min.) } & \multicolumn{6}{|c|}{ Output Pepsin (mg. tyrosine/15 min.) } \\
\hline & & \multicolumn{3}{|c|}{ Control } & \multicolumn{3}{|c|}{ SU 4885} & \multicolumn{3}{|c|}{ Control } & \multicolumn{3}{|c|}{ SU 4885} & \multicolumn{3}{|c|}{ Control } & \multicolumn{3}{|c|}{ SU 4885} \\
\hline & & $I^{*}$ & II & III & I & II & III & I & II & III & I & II & III & I & II & III & I & II & III \\
\hline $\begin{array}{l}\text { Benefit } \\
\text { Response } \\
\text { Control }\end{array}$ & $\begin{array}{l}\mathbf{A} \\
\mathbf{B} \\
\mathbf{C}\end{array}$ & $\begin{array}{l}4 \cdot 4 \\
7 \cdot 1 \\
6 \cdot 6\end{array}$ & $\begin{array}{l}5.0 \\
7 \cdot 3 \\
6 \cdot 7\end{array}$ & $\begin{array}{l}5.0 \\
7.5 \\
6.1\end{array}$ & $\begin{array}{l}4.9 \\
6 \cdot 9 \\
6 \cdot 4\end{array}$ & $\begin{array}{l}4 \cdot 7 \\
7 \cdot 3 \\
7 \cdot 2\end{array}$ & $\begin{array}{l}4.9 \\
7.0 \\
6.5\end{array}$ & $\begin{array}{l}0.603 \\
0.919 \\
0.996\end{array}$ & $\begin{array}{l}0.684 \\
1.076 \\
1.028\end{array}$ & $\begin{array}{l}.700 \\
1.109 \\
0.929\end{array}$ & $\begin{array}{l}0.653 \\
0.924 \\
0.881\end{array}$ & $\begin{array}{l}0.596 \\
1.018 \\
1.012\end{array}$ & $\begin{array}{l}0.605 \\
0.954 \\
0.930\end{array}$ & $\begin{array}{r}8 \cdot 7 \\
12 \cdot 8 \\
26 \cdot 2\end{array}$ & $\begin{array}{l}10 \cdot 1 \\
23 \cdot 6 \\
29 \cdot 5\end{array}$ & $\begin{array}{l}11.8 \\
16.7 \\
24.0\end{array}$ & $\begin{array}{l}11.2 \\
17.6 \\
39.9\end{array}$ & $\begin{array}{r}9 \cdot 1 \\
19 \cdot 2 \\
37 \cdot 9\end{array}$ & $\begin{array}{l}11.9 \\
22 \cdot 3 \\
2.9 \cdot 1\end{array}$ \\
\hline
\end{tabular}

*I = mean of six collections before SU 4885; II = mean of nine collections after SU 4885; III = mean of six collections after cortisol.

The absence of significant effect was confirmed by an analysis of variance of the mean logarithms of the outputs of juice, acid, and pepsin in the control tests in all three dogs and in these carried out after SU 4885.

Response to Mecothane.-The intravenous injection of SU 4885 (15 mg. per kg. body weight) was similarly without significant effect on the outputs of juice, acid, and pepsin secreted in response to a continuous subcutaneous infusion of "mecothane" (Fig. 2 and Table II). This also was confirmed by an analysis of variance of the logarithms of the outputs.

Histamine.-Neither the injection of SU 4885 (15 mg. per kg. body weight) nor that of cortisol (100 mg.) had any effect on the secretory response to a continuous subcutaneous infusion of histamine acid phosphate $(25 \mu \mathrm{g}$. base $/ \mathrm{kg}$./hr. $)$. The results of these tests are shown graphically in Fig. 3. The 

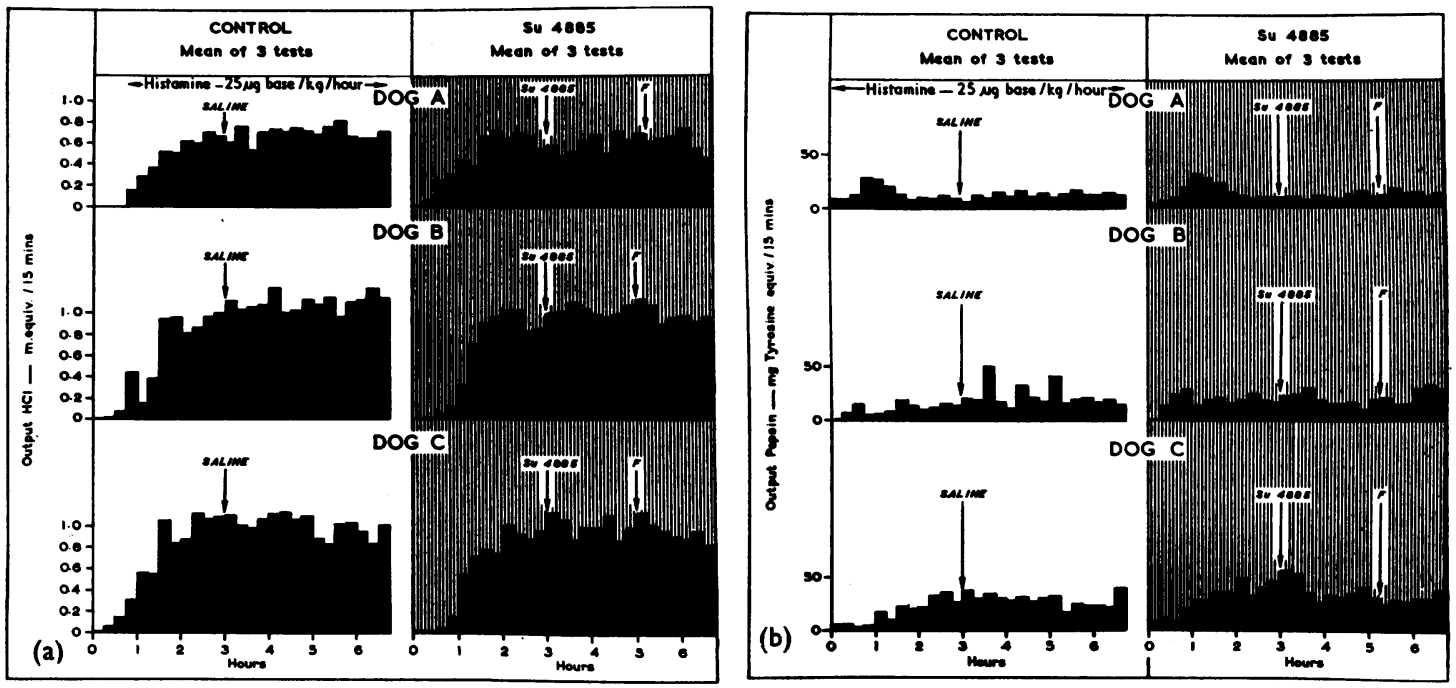

FIG. 3.-The effect of SU 4885 (15 mg./kg. intravenously) and cortisol (100 mg. intravenously) on the outputs of

(a) acid and (b) pepsin from Heidenhain pouches of the stomach stimulated by a continuous subcutaneous injection of histamine acid phosphate (or $25 \mathrm{mg}$. base $/ \mathrm{kg} . / \mathrm{hr}$.) in three dogs.

mean outputs of juice, acid, and pepsin for six 15-minute collections before SU 4885 (Tables I-III), nine 15-minute collections after SU 4885 (Table II), and six 15-minute collections after cortisol (Table III) were calculated for each dog and compared with those of the corresponding periods of the control tests. No obvious difference was noted (Table III).

INGESTION OF SU 4885.-In three of the four dogs studied free acid was present in the gastric juice during the control period. In these three dogs the ingestion of SU 4885 resulted in a reduction in the output of acid from the Heidenhain pouch (Fig. 4 and Table IV). The difference between the means of the logarithms of the outputs of acid during the control period and that in which SU 4885 was ingested were statistically significant in each animal (Table V).

One of these three dogs died from peritonitis after retraction of the pouch during the experiment. In the other two dogs the acid output returned to the control level when SU 4885 was discontinued, and the difference between the outputs of acid during the period of SU 4885 ingestion and that following its withdrawal was again significant (Table V). The fourth dog had no free acid in its gastric juice during any phase of the experiment.

The inhibition of the output of acid was largely due to a reduction of concentration of acid in the secreted juice, and the slight reduction in the volume of juice in the three dogs which secreted free acid was insignificant. In the fourth $\operatorname{dog}(\operatorname{Dog} F)$, which had no free acid in the gastric juice, the volume was increased during the period of SU 4885 administration.

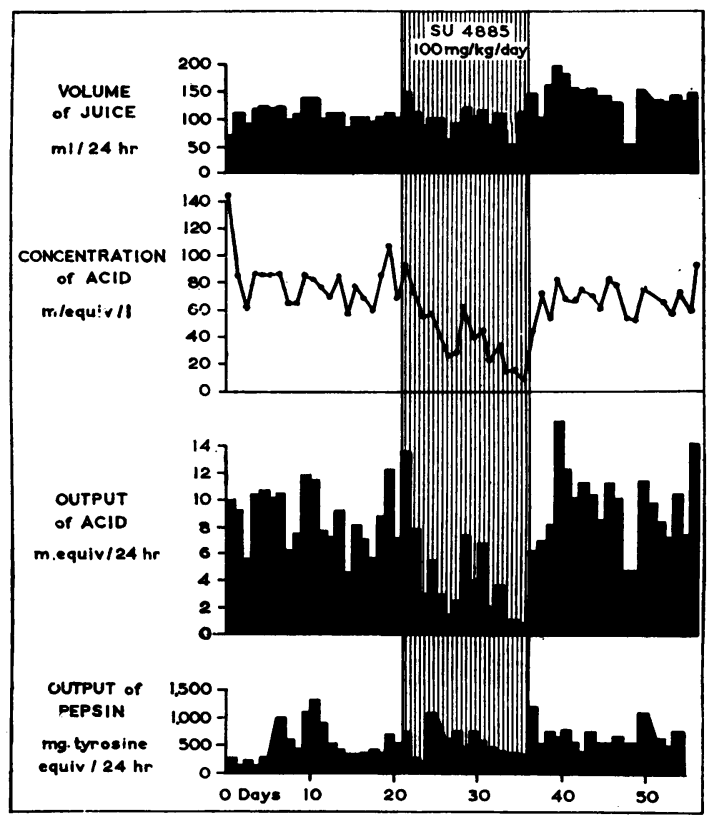

FIG. 4.-The effect of oral ingestion of SU 4885 (100 mg./ kg./day) on the daily outputs of juice, acid, and pepsin from a Heidenhain pouch of the stomach in a dog. 
TABLE IV

EFFECT OF SU 4885 ON 24-HOUR SECRETION FROM SEPARATED POUCHES IN FOUR DOGS

\begin{tabular}{|c|c|c|c|c|c|c|}
\hline Dog & SU 4885 & $\begin{array}{l}\text { No. of } \\
\text { Collections }\end{array}$ & $\begin{array}{c}\text { Volume Juice } \\
\text { (ml./24 hr.) }\end{array}$ & $\underset{(\mathrm{mEq} . / 1 .)}{\text { Concentration } \mathrm{HCl}}$ & $\begin{array}{l}\text { Output } \mathbf{H C l} \\
\text { (mEq./24 hr.) }\end{array}$ & $\begin{array}{l}\text { Output Pepsin } \\
\text { (mg. tyrosine eq. } / 24 \mathrm{hr} \text { ) }\end{array}$ \\
\hline D & $\begin{array}{l}\text { Before } \\
\text { During } \\
\text { After }\end{array}$ & $\begin{array}{l}21 \\
14 \\
19\end{array}$ & $\begin{array}{l}113 \\
100 \\
141\end{array}$ & $\begin{array}{l}77 \\
39 \\
64\end{array}$ & $\begin{array}{l}9 \cdot 1 \\
4 \cdot 9 \\
9 \cdot 5\end{array}$ & $\begin{array}{l}517 \\
528 \\
659\end{array}$ \\
\hline $\mathbf{E}$ & $\begin{array}{l}\text { Before } \\
\text { During } \\
\text { After }\end{array}$ & $\begin{array}{l}10 \\
15 \\
17\end{array}$ & $\begin{array}{l}48 \\
47 \\
53\end{array}$ & $\begin{array}{l}62 \\
39 \\
58\end{array}$ & $\begin{array}{l}2.9 \\
1.9 \\
3.4\end{array}$ & $\begin{array}{l}465 \\
435 \\
378\end{array}$ \\
\hline $\mathbf{F}$ & $\begin{array}{l}\text { Before } \\
\text { During } \\
\text { After }\end{array}$ & $\begin{array}{l}21 \\
15 \\
18\end{array}$ & $\begin{array}{l}34 \\
50 \\
44\end{array}$ & $\begin{array}{l}\mathbf{0} \\
\mathbf{0} \\
\mathbf{0}\end{array}$ & $\begin{array}{l}\mathbf{0} \\
\mathbf{0} \\
\mathbf{0}\end{array}$ & $\begin{array}{l}248 \\
505 \\
213\end{array}$ \\
\hline G & $\begin{array}{l}\text { Before } \\
\text { During } \\
\text { After }\end{array}$ & $\begin{array}{r}6 \\
7 \\
-\end{array}$ & $\begin{array}{r}217 \\
184 \\
\end{array}$ & $\begin{array}{r}107 \\
84 \\
\end{array}$ & $\begin{array}{r}23 \cdot 2 \\
15 \cdot 7 \\
-\end{array}$ & $\begin{array}{l}488 \\
763 \\
-\end{array}$ \\
\hline
\end{tabular}

TABLE V

ANALYSIS OF ACID OUTPUTS

\begin{tabular}{|c|c|c|c|c|}
\hline Dog & SU 4885 & Mean Log. Acid Output & Mean Difference Log. & $\mathbf{P}$ \\
\hline D & $\begin{array}{l}\text { Before } \\
\text { During } \\
\text { After }\end{array}$ & $\left.\begin{array}{l}0.932 \\
0.509 \\
0.954\end{array}\right\}$ & $\begin{array}{l}0.423 \pm 0.045^{*} \\
0.445 \pm 0.046\end{array}$ & $\begin{array}{l}<0.001 \\
<0.001\end{array}$ \\
\hline $\mathbf{E}$ & $\begin{array}{l}\text { Before } \\
\text { During } \\
\text { After }\end{array}$ & $\left.\begin{array}{l}0.437 \\
0.267 \\
0.459\end{array}\right\}$ & $\begin{array}{l}0.170 \pm 0.030 \\
0.192 \pm 0.081\end{array}$ & $\begin{array}{l}<0.001 \\
<0.05\end{array}$ \\
\hline $\mathbf{F}$ & $\begin{array}{l}\text { Before } \\
\text { During } \\
\text { After }\end{array}$ & 二 & E & 二 \\
\hline $\mathbf{G}$ & $\begin{array}{l}\text { Before } \\
\text { During }\end{array}$ & $\left.\begin{array}{l}1 \cdot 350 \\
1 \cdot 180\end{array}\right\}$ & $0.169 \pm 0.071$ & $<0.05$ \\
\hline
\end{tabular}

* Standard error of means.

TABLE VI

ANALYSIS OF 24-HOUR VOLUME OF JUICE

\begin{tabular}{|c|c|c|c|c|}
\hline Dog & SU 4885 & $\begin{array}{c}\text { Mean Volume } \\
\text { Juice Dog } \\
\text { (ml./24 hr.) }\end{array}$ & $\begin{array}{c}\text { Mean } \\
\text { Difference }\end{array}$ & $\mathbf{P}$ \\
\hline D & $\begin{array}{l}\text { Before } \\
\text { During } \\
\text { After }\end{array}$ & $\left.\begin{array}{l}2.035 \\
1.982 \\
2 \cdot 142\end{array}\right\}$ & $\begin{array}{l}0.053 \pm 0.036 \\
0.160 \pm 0.037\end{array}$ & $\begin{array}{l}>0.1 \\
<0.01\end{array}$ \\
\hline $\mathbf{E}$ & $\begin{array}{l}\text { Before } \\
\text { During } \\
\text { After }\end{array}$ & $\left.\begin{array}{l}1.676 \\
1.666 \\
1.688\end{array}\right\}$ & $\begin{array}{l}0.010 \pm 0.027 \\
0.022 \pm 0.051\end{array}$ & $\begin{array}{l}>0.7 \\
>0.6\end{array}$ \\
\hline $\mathbf{F}$ & $\begin{array}{l}\text { Before } \\
\text { During } \\
\text { After }\end{array}$ & $\left.\begin{array}{l}1.519 \\
1.692 \\
1.669\end{array}\right\}$ & $\begin{array}{l}0.173 \pm 0.032 \\
0.023 \pm 0.027\end{array}$ & $\begin{array}{l}<0.001 \\
>0.3\end{array}$ \\
\hline $\mathbf{G}$ & $\begin{array}{l}\text { Before } \\
\text { During } \\
\text { After }\end{array}$ & $\left.\begin{array}{l}2 \cdot 322 \\
2 \cdot 257\end{array}\right\}$ & $0.065 \pm 0.060$ & $>0.3$ \\
\hline
\end{tabular}

TABLE VII

ANALYSIS OF 24-HOUR OUTPUT OF PEPSIN

\begin{tabular}{|c|c|c|c|c|}
\hline Dog & SU 4885 & $\begin{array}{c}\text { Mean Output } \\
\text { Pepsin } \\
\text { (log. mg. } \\
\text { tyrosine } \\
\text { eq. } / 24 \text { hr.) }\end{array}$ & $\begin{array}{c}\text { Mean } \\
\text { Difference }\end{array}$ & $\mathbf{P}$ \\
\hline $\mathbf{D}$ & $\begin{array}{l}\text { Before } \\
\text { During } \\
\text { After }\end{array}$ & $\left.\begin{array}{l}2 \cdot 631 \\
2 \cdot 681 \\
2 \cdot 822\end{array}\right\}$ & $\begin{array}{l}0.050 \pm 0.093 \\
0.141 \pm 0.095\end{array}$ & $\begin{array}{l}>0.4 \\
>0.1\end{array}$ \\
\hline $\mathbf{E}$ & $\begin{array}{l}\text { Before } \\
\text { During } \\
\text { After }\end{array}$ & $\left.\begin{array}{l}2 \cdot 645 \\
2 \cdot 608 \\
2 \cdot 549\end{array}\right\}$ & $\begin{array}{l}0.037 \pm 0.073 \\
0.059 \pm 0.057\end{array}$ & $\begin{array}{l}>0.6 \\
>0.3\end{array}$ \\
\hline $\mathbf{F}$ & $\begin{array}{l}\text { Before } \\
\text { During } \\
\text { After }\end{array}$ & $\left.\begin{array}{l}2 \cdot 347 \\
2.656 \\
2 \cdot 295\end{array}\right\}$ & $\begin{array}{l}0.309 \pm 0.074 \\
0.361 \pm 0.077\end{array}$ & $\begin{array}{l}<0.01 \\
<0.01\end{array}$ \\
\hline $\mathbf{G}$ & $\begin{array}{l}\text { Before } \\
\text { During }\end{array}$ & $\left.\begin{array}{l}2 \cdot 664 \\
2 \cdot 866\end{array}\right\}$ & $0.202 \pm 0.077$ & $<0.05$ \\
\hline
\end{tabular}

The output of pepsin, as is normal in denervated pouches, was low, and in none of the four dogs was it significantly reduced by SU 4885 . In two dogs (Dogs F and G) the output of pepsin was increased while the drug was being taken (Table VII).

\section{Discussion}

It is clear from these experiments that the administration of SU 4885 by single intravenous injection is without effect on the immediate secretory response of canine Heidenhain pouches to the ingestion of meat or subcutaneous "mecothane" or histamine. However, when the drug was administered by mouth over a period of 10 to 14 days the 24-hour output of acid from Heidenhain pouches was decisively inhibited, this effect being due to a reduction in the concentration of acid in the gastric juice. The volume of juice and output of pepsin were not significantly influenced by SU 4885 administered in this way.

It is not possible to claim on this evidence that the effect of the drug is mediated by its properties to inhibit adrenocortical function, and in the absence of further supplies experimental proof of the nature of its action must necessarily be delayed. Nevertheless, certain similarities between the nature of its action and that of corticotrophin and cortisone provide circumstantial evidence that its action on 
gastric secretory function is due to such a mechanism.

There is now considerable evidence that the prolonged administration of corticotrophin or cortisone stimulates the secretion of acid from Heidenhain pouches in dogs (Zubiran, Kark, and Dragstedt, 1952; Zubiran, Kark, Montalbetti, Morel, and Dragstedt, 1952; Villarreal, Ganong, and Gray, 1955; McGee, Blackburn, Lance, and Scott, 1959; Clarke, Neill, and Welbourn, 1960). Administration of these hormones over a shorter period of time is more uncertain in its effect (Ragins, Dragstedt, Landor, Lyon, and Dragstedt, 1956; Clarke et al., 1960), and Clarke et al. found that it requires three to four days for stimulation.

A similar time-effect relationship was noted in our studies with SU 4885, and it was only with prolonged administration that an inhibitory action was revealed.

Both Villarreal et al. (1955) and Clarke et al. (1960) found that the effect of corticotrophin and cortisone on secretion from the Heidenhain pouch was primarily on the concentration of acid secreted, the volume being affected to a less extent. Other workers have found that the volume also may be increased (Zubiran et al., 1952a and b; McGee et al., 1959) although the large 24-hour volumes of juice collected from the pouches (249 to $750 \mathrm{ml}$.) are greatly in excess of those in this study and may more readily reflect a change. McGee et al. assumed from their $p \mathrm{H}$ records that the action of cortisone was mainly in the volume of juice secreted and that the concentration of acid was affected to a less extent. However, if the concentration of acid is calculated from their data it is found that during administration of cortisone it was increased from 106 to $136 \mathrm{mEq}$./1., a change which, although of little effect on the $p \mathrm{H}$ of the juice, is nevertheless in keeping with that described by others.

The action of SU 4885 in our dogs is again comparable, the reduction of acid output from the pouches being due mainly to a reduction in the concentration of acid in the secreted juice.

The effect of corticotrophin and cortisone on the secretion of pepsin from Heidenhain pouches of the stomach is less well documented. The findings of Villarreal et al. (1955) that this was markedly increased during corticotrophin administration were not confirmed by Clarke et al. (1960). Our finding that SU 4885 was without effect on the secretion of pepsin therefore is not evidence against its action on gastric secretion being secondary to adrenal depression of cortisol secretion.

It is concluded that the adrenal inhibitor SU 4885, administered over a prolonged period, inhibits the secretion of acid from canine Heidenhain pouches. The nature of its action must meantime remain obscure although it appears reasonable to suppose that it is mediated by adrenocortical inhibition.

\section{SUMmarY}

The action of the adrenocortical inhibitor, SU 4885, has been studied in dogs with separated pouches of the stomach of Heidenhain type.

In the first group of experiments in three dogs the drug was given by single intravenous injection during the secretory response to (1) ingestion of a meal of meat, (2) subcutaneous mecothane, and (3) subcutaneous histamine. No effect was noted.

In the second group of experiments the drug was given orally for seven to 15 days to four dogs on a constant diet and juice collected serially every 24 hours. Under these conditions SU 4885 reduced the secretion of acid from the stomach pouches.

We wish to thank Professor C. F. W. Illingworth, in whose department this work was carried out, for his help. Professor R. C. Garry kindly allowed us to house the dogs in the Institute of Physiology in the University of Glasgow and we are grateful to him and to his animal house technicians for their assistance. The SU 4885 was supplied by Ciba Laboratories Ltd., and we are grateful to Dr. C. D. Falconer for his cooperation.

\section{REFERENCES}

Chart, J. J., Sheppard, H., Allen, M. J., Bencze, W. L., and Gaunt, R. (1958). Experientia (Basel.), 14, 151-152.

Clarke, S. D., Neill, D. W., and Welbourn, R. B. (1960). Gut., 1, 36-43.

Coppage, W. S. Jr., Island, D., Smith, M., and Liddle, G. W. (1959). J. clin. Invest., 38, 2101 .

Grant, J. K. (1961). Human Adrenal Cortex. Proceedings of Conference at the University of Glasgow. Livingstone: Edinburgh. In the press.

Hunt, J. N. (1948). Biochem. J., 42, 104.

Jenkins, J. S. (1959). Proc. roy. Soc. Med., 52, 260.

Meakin, J. W., Nelson, D. H., and Thorn, G. W. (1958). Science, 128-478-480.

Liddle, G. W., Island, D., Lance, E. M., and Harris, A. P. (1958). J. clin. Endocr., 18, 906.

McGee, L. S. Jr., Blackburn, J., Lance, E. M., and Scott, H. W. Jr. (1959). Surg. Forum, 1958), 9, 440.

Ragins, H., Dragstedt, L. R.II, Landor, J. H., Lyon, E. S., and Dragstedt, L. R.'(1956). Surgery, 40, 886.

Villarreal, R., Ganong, W. F., and Gray, S. J. (1955). Amer. J. Physiol., 183, 485.

Zubiran, J. M., Kark, A. E., and Dragstedt, L. R. (1952a). Gastroenterology, 21, 276.

, Montalbetti, A. J., Morel, C. J. L., and Dragstedt, L.R, (1952b). A.M.A. Arch. Surg., 65, 809. 